
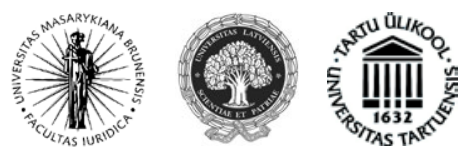

\title{
TEISMŲ PRAKTIKOS AKTUALIJOS BAUDŽIAMOSIOSE BYLOSE DĖL JURIDINIŲ ASMENŲ PADARYTŲ NUSIKALSTAMŲ VEIKŲ
}

\author{
Jolanta Zajančkauskienè \\ Mykolo Romerio universiteto Teisès fakulteto \\ Baudžiamosios teisès ir proceso institutas \\ Ateities g. 20, LT-08303 Vilnius, Lietuva \\ Telefonas (+370 5) 2714639 \\ Elektroninis paštas zajan@mruni.eu
}

Pateikta spausdinti 2013 m. gruodžio 20 d., parengta spausdinti 2014 m. sausio 16 d.

doi:10.13165/JUR-13-20-4-14

\section{Ivadas}

2009 m. birželio 8 d. Lietuvos Respublikos Konstitucinis Teismas (toliau ir Konstitucinis Teismas) prièmė nutarimą „Dėl Baudžiamojo kodekso 20 straipsnio 1, 2, 3 ir 5 dalių ir 43 straipsnio 4 dalies atitikties Lietuvos Respublikos Konstitucijai" ${ }^{\text {"1 }}$ Šiuo nutarimu buvo pripažinta, kad juridinio asmens baudžiamosios atsakomybės taikymo pagrindai ir sąlygos, įtvirtintos Lietuvos Respublikos baudžiamajame kodekse (toliau ir Baudžiamasis kodeksas, BK) ${ }^{2}$, neprieštarauja Lietuvos Respublikos Konstitucijai. Nors minètas Konstitucinio Teismo nutarimas ir atsakè ị daugeli klausimų dèl juridinių asmenų baudžiamosios atsakomybès, tačiau Lietuvos teismų praktika nuolat iškelia vis

1 Lietuvos Respublikos Konstitucinio Teismo 2009 m. birželio 8 d. nutarimas „Dèl Lietuvos Respublikos baudžiamojo kodekso 20 straipsnio 1, 2, 3 dalių (2000 m. rugsèjo $26 \mathrm{~d}$. redakcija), 20 straipsnio 5 dalies (2004 m. liepos 5 d. redakcija) 43 straipsnio 4 dalies (2000 m. rugsèjo 26 d. redakcija) atitikties Lietuvos Respublikos Konstitucijai“. Valstybès žinios. 2009, Nr. 69-2798.

2 Lietuvos Respublikos baudžiamasis kodeksas. Valstybės žinios. 2000, Nr. 89-2741 (aktuali redakcija). 
naujų probleminių aspektų, susijusių tiek su juridinių asmenų baudžiamosios atsakomybès taikymo pagrindais ir sąlygomis, tiek su ikiteisminiu tyrimu bei baudžiamųjų bylų nagrinėjimu dẻl juridinių asmenų padarytų nusikalstamų veikų.

Šiame darbe pateikiami kai kurie teismų praktikos pavyzdžiai ${ }^{3}$, kurie yra svarbūs sprendžiant juridinio asmens baudžiamosios atsakomybès klausimus. Ypatingas dèmesys yra skiriamas Lietuvos Aukščiausiojo Teismo Baudžiamujų bylų skyriaus $2012 \mathrm{~m}$. sausio 10 d. nutarčiai baudžiamojoje byloje Nr. 2K-P-95/2. Šioje nutartyje yra analizuojama Baudžiamojo kodekso 20 straipsnio 2 dalies turinys bei itin praktikoje probleminis juridinio asmens kaltès nustatymas. Be to, darbe nurodomi teismų praktikos pavyzdžiai, iliustruojantys procesinius baudžiamųjų bylų dẻ juridinių asmenų padarytų nusikalstamų veikų ypatumus, kurie yra reguliuojami Lietuvos Respublikos baudžiamojo proceso kodekse $^{4}$ (toliau ir Baudžiamojo proceso kodeksas, BPK). Šiame kontekste skiriama traukiamo baudžiamojon atsakomybèn juridinio asmens atstovavimas bei laikinų procesinių prievartos priemonių taikymas.

\section{Juridinio asmens apibrěžtis pagal BK 20 straipsnị}

Lietuvos Respublikos Konstitucinis Teismas ${ }^{5}$ aiškindamas sąvokas, svarbias BK 20 straipsnio prasme, pabrèžè, kad jos turi būti aiškinamos ne tik sistemiškai tarpusavyje, bet ir kartu su kituose ịstatymuose ịtvirtintomis nuostatomis, reguliuojančiomis juridinio asmens valdymo organų sudarymą, teisių ir pareigų igyvendinimą ir kt. Pavyzdžiui, Lietuvos Respublikos civiliniame odekse $^{6}$ (toliau ir CK) yra ittvirtintas juridinio asmens sąvokos apibrèžimas, juridinių asmenų skirstymas ị viešuosius juridinius asmenis ir privačius juridinius asmenis ir kt. Be to, CK 2.95 straipsnyje yra nurodoma, kad juridiniai asmenys pasibaigia likvidavimo arba reorganizavimo būdu, o kodekso 2.104 straipsnyje nustatyta juridinio asmens teisinès formos keitimo procedūra - juridinių asmenų pertvarkymas. Pertvarkymas nėra juridinio asmens reorganizavimas, nes juridinis asmuo nepasibaigia, o tik keičia teisinę formą.

Antai,$<\ldots>$ trunkamasis juridinio asmens padarytas nusikaltimas teisésaugos instituciju nutrauktas $2007 \mathrm{~m}$. balandžio 17 d. tuo metu, kai neteisèta ūkine ir komercine veikla vertèsi ne $U A B$ „I. “, o A. Č. individuali įmone „I. “. Ši ịmonè turèjo juridinio asmens statusą, kaip apibrèžta CK 2.33 straipsnyje. Apeliacinès instancijos teismas konstatavo, kad ši ịmone, remiantis CK 2.95 straipsniu, nepasibaigusi, t. y. nebuvo reorganizuota ar likviduota. Taip pat teismas nuosprendyje nurode, kad $2008 \mathrm{~m}$. kovo

3 Kai kurie teismų praktikos pavaizdžiai jau buvo publikuoti autorès darbe Ažubalyte, R.; Jurgaitis, R.; Zajančkauskienè, J. Specifinès baudžiamojo proceso rūšys. Vilnius: Mykolo Romerio universitetas, 2011, p. $185-216$.

4 Lietuvos Respublikos baudžiamojo proceso kodeksas. Valstybès žinios. 2002, Nr. 37 (aktuali redakcija).

5 Lietuvos Respublikos Konstitucinio Teismo 2009 m. birželio 8 d. nutarimas „Dèl Lietuvos Respublikos baudžiamojo kodekso 20 straipsnio 1, 2, 3 dalių (2000 m. rugsèjo 26 d. redakcija), 20 straipsnio 5 dalies (2004 m. liepos 5 d. redakcija) 43 straipsnio 4 dalies (2000 m. rugsèjo 26 d. redakcija) atitikties Lietuvos Respublikos Konstitucijai“, supra note 1.

6 Lietuvos Respublikos civilinis kodeksas. Valstybès žinios. 2000, Nr. 74-2262 (aktuali redakcija). 
14 d. A. Č. individuali įmonè „I. “ buvo pertvarkyta i UAB „I. “ir atkreipè demesį, kad CK 2.104 straipsnio 1 dalyje numatyta, jog pertvarkymas - tai juridinio asmens teisinès formos pakeitimas, kai naujos teisinès formos juridinis asmuo perima visas pertvarkytojo juridinio asmens teises ir pareigas.

Tokios konstatuotos bylos aplinkybès rodo, kad pasikeite individualios ịmonès ,I.“ “ juridinio asmens teisine forma, tačiau toks teisinès formos pakeitimas nèra juridinio asmens pabaiga (kasacine nutartis Nr. 2K-355/2010).

$<\ldots>$ Taigi apeliacinès instancijos išvada, kad UAB ,I. “ nèra BK nusikaltimo subjektas ir nenustatyta šio juridinio asmens kalté, prieštarauja faktinèms aplinkybèms. "7

\section{Juridinio asmens patraukimo baudžiamojon atsakomybèn sąlygos (BK 20 straipsnio 2 dalis)}

Baudžiamoji atsakomybė pagal Baudžiamojo kodekso 20 straipsnio 2 dali juridiniam asmeniui gali kilti tuomet, kai jo naudai ar interesais nusikalstamą veiką padaro fizinis asmuo, kuris eina vadovaujančias pareigas tame juridiniame asmenyje ir turi teise arba atstovauti juridiniam asmeniui, arba priimti sprendimus juridinio asmens vardu, arba kontroliuoti juridinio asmens veikla (išskirta aut.).

Pavyzdžiui, Lietuvos Aukščiausiojo Teismo Baudžiamujų bylų skyriaus teisejų kolegija konstatavo, kad pirmosios instancijos teismas juridinį asmenį UAB „S.“ pagrịstai pripažino kaltu pagal Baudžiamojo kodekso 20 straipsnio 2 dalị ir 300 straipsnio 1 dalị. Byloje buvo nustatyta, kad nusikalstamą veiką - žinomai suklastoto tikro dokumento panaudojimą - padare D. L., kuris veikos metu buvo UAB „S.“ direktorius (vadovaujančios pareigos), pagal šios bendroves įstatus turintis teisę juridinio asmens vardu priimti sprendimus bei kontroliuoti juridinio asmens veiklą. Buvo nustatyti D. L. kaip fizinio asmens specifiniai požymiai, kurie yra viena iš privalomų sąlygų norint patraukti juridinị asmenị baudžiamojon atsakomybèn. D. L. vadovaujančios pareigos suteikẻ galimybę teikti kitiems juridinio asmens darbuotojams privalomus nurodymus bei formuoti juridinio asmens ar jo struktūrinès dalies veiklos kryptis ${ }^{8}$.

Kitoje baudžiamojoje byloje pagristai buvo nustatyta, jog nusikalstamas veikas padare UAB „X“ direktorius M. M., kuris tuo metu èjo vadovaujančias pareigas juridiniame asmenyje ir turejo teisę atstovauti juridiniam asmeniui, priimti sprendimus juridinio asmens vardu ir kontroliuoti juridinio asmens veiklą. Tokiu būdu buvo nustatyta, kad M. M. yra fizinis asmuo, ịvardytas BK 20 straipsnio 2 dalyje ir turintis atitinkamą teisini statusą ${ }^{9}$.

7 Lietuvos Aukščiausiojo Teismo Baudžiamujų bylų skyriaus 2010 m. gruodžio 23 d. nutartis baudžiamojoje byloje Nr. 2K-581/2010; Lietuvos Aukščiausiojo Teismo Baudžiamujjų bylų skyriaus $2010 \mathrm{~m}$. liepos 2 d. nutartis baudžiamojoje byloje Nr. 2K-355/2010.

8 Lietuvos Aukščiausiojo Teismo Baudžiamųų bylų skyriaus $2010 \mathrm{~m}$. balandžio 27 d. nutartis baudžiamojoje byloje Nr. 2K-269/2010.

9 Vilniaus miesto 1-ojo apylinkès teismo $2011 \mathrm{~m}$. vasario 4 d. nuosprendis baudžiamojoje byloje Nr. 1-175$865 / 2011$. 
Kita juridinio asmens baudžiamosios atsakomybės sąlyga yra nusikalstamos veikos padarymas individualiai ar juridinio asmens vardu ir juridinio asmens naudai arba jo interesais (BK 20 straipsnio 2 dalis) (išskirta aut.). Nauda paprastai yra aiškinama kaip turtinès naudos gavimas, o interesų užtikrinimas - kaip reiškiantis kitų (nebūtinai turtinių) juridinio asmens siekių ígyvendinimą. „Intereso“ sąvoka platesnè nei „naudos“ sąvoka ir gali apimti pastarają ${ }^{10}$. „Konstatuojant šia juridinio asmens baudžiamosios atsakomybès sąlyga turi büti nustatyta, kad iš nusikalstamos fizinio asmens veikos juridinis asmuo turi (turès) naudos ir ta nauda pripažista (pvz., neteisètu būdu išgryninti pinigai, naudojami ịmonès interesams užtikrinti) arba kai juridinis asmuo suinteresuotas tokia veika ir jos sukuriamais padariniais (pvz., juridinio asmens panaudojimas darant nusikalstama veika buvo realiai naudingas: įmonès ūkinès veiklos perspektyvai ir jos konkurencingumui; ìmonès ịvaizdžiui; ar suteikè i̇monei kokiu nors pranašumu prieš kitas įmones konkuruojant viešuju pirkimu konkursuose). "11 Juridinio asmens nauda ar interesas yra alternatyvios jo atsakomybės sąlygos, iš kurių bent vieną būtina nustatyti. Be to, atkreiptinas dėmesys ị tai, kai kaltininkas - fizinis asmuo, kurio igaliojimai nustatyti BK 20 straipsnio 2 dalyje, savo nusikalstama veika yra gavęs turtinę naudą, pavyzdžiui, pasisavinęs juridinio asmens pinigus, būtina tirti, kur buvo naudojami fizinio asmens pasisavinti pinigai: asmeniniams poreikiams ar bendrovès naudai ar interesais ${ }^{12}$.

Antai baudžiamojoje byloje ${ }^{13}$ teismai pagrịstai nustatè, kad dèl kaltininko - fizinio asmens - neteisètos veikos juridinis asmuo gavo tiesioginės materialinès naudos. Tokia išvada buvo pagrịsta nuteistųjų parodymais apie gautų piniginių lěšų panaudojimą. Šie asmenys paaiškino, kad, bendrovei pritrūkus apyvartinių lěšų, buvo nuspręsta grynų pinigų gauti išrašant netikras sąskaitas faktūras už iš tikrųų nesuteiktas kitos įmonès paslaugas, o šiai sumokètus pinigus vėliau susigrąžinti. Tokiu būdu veikiant atgavus kitai bendrovei sumokètus pinigus ir gavus papildomą pinigų sumą už nesumokètą valstybei PVM, šie pinigai buvo panaudoti kaltinamosios bendrovès (UAB ,T") veiklos reikmėms: iš konkurentų perpus pigiau perkamos medžiagos bei įrankiai, kurie buvo naudojami kasdieninèje įmonès veikloje, keliskart pigiau išnuomoti keltuvai, atliekami darbai, kurių nebuvo galima pagrịsti sąskaitomis, sumokèta bendrovès darbininkams už atliktus darbus, neiforminant to dokumentuose, ir pan. Aplinkybè, kad sprendimą neteisètu būdu išgrynintus pinigus panaudoti minètomis kryptimis kaltinamas įmonès vadovas prièmè individualiai, nepaneigè fakto, kad lèšos buvo panaudotos įmonès naudai. Kaltinamasis įmonès vadovas V. R. teisme patvirtino, kad jis veikè bendrovès in-

10 Lietuvos Aukščiausiojo Teismo Baudžiamųjų bylų skyriaus $2012 \mathrm{~m}$. sausio 10 d. nutartis baudžiamojoje byloje Nr. 2K-P-95/2012.

11 Ibid.

12 Lietuvos Aukščiausiojo Teismo Baudžiamųjų bylų skyriaus $2012 \mathrm{~m}$. sausio 10 d. nutartis baudžiamojoje byloje Nr. 2K-P-95/2012; Lietuvos Aukščiausiojo Teismo Baudžiamujų bylų skyriaus 2010 m. gruodžio 21 d. nutartis baudžiamojoje byloje Nr. 2K-582/2010; Lietuvos Aukščiausiojo Teismo Baudžiamujų bylų skyriaus 2010 m. gruodžio 14 d. nutartis baudžiamojoje byloje Nr. 2K-575/2010; Lietuvos Aukščiausiojo Teismo Baudžiamujų bylų skyriaus 2010 m. lapkričio 9 d. nutartis baudžiamojoje byloje Nr. 2K479/2010; Lietuvos Aukščiausiojo Teismo Baudžiamųjų bylų skyriaus 2010 m. balandžio 27 d. nutartis baudžiamojoje byloje Nr. 2K-269/2010.

13 Lietuvos Aukščiausiojo Teismo Baudžiamųų bylų skyriaus $2011 \mathrm{~m}$. birželio 28 d. nutartis baudžiamojoje byloje Nr. 2K-345/2011. 
teresais, siekdamas jai gerovės. Finansinių nusikaltimų tyrimo tarnybos prie Lietuvos Respublikos vidaus reikalų ministerijos ūkinès finansinès veiklos tyrimo Vilniaus apskrities skyriaus specialisto išvada dèl UAB ,T.“ ūkinès finansinès veiklos tyrimo, kuria rèmèsi teismai, buvo nustatyta, kad i UAB ,T." buhalterinę apskaitą įtrauktos suklastotos sąskaitos faktūros buvo panaudotos paruošiant PVM deklaraciją ir dėl to 10800 Lt buvo sumažinta UAB „T.“ privaloma mokèti PVM mokesčio suma už 2006 metus ${ }^{14}$. Mokesčių mokèjimo išvengimas arba jų sumažinimas pripažintinas materialine nauda. Kita vertus, juridinis asmuo, išvengdamas sumokèti apibrèžtą sumą mokesčių ì valstybès biudžetą, igavo pranašumą prieš kitas, sąžiningai mokesčius mokančias įmones ir taip gavo nematerialinès naudos. Konstatuotina, kad UAB ,T“ dèl jos vadovo atliktų neteisètų veiksmų gavo tiek realios materialinès, tiek nematerialinès naudos, o nuteistasis V. R. veikè bendrovès naudai ir interesais ${ }^{15}$.

\section{Juridinio asmens kaltè}

BK 2 straipsnio 3 dalyje nustatyta, kad asmuo atsako pagal baudžiamaji įstatymą tik tuo atveju, jeigu jis yra kaltas padaręs nusikalstamą veiką. BK 20 straipsnyje ịtvirtintą teisinį reguliavimą aiškinant kartu su BK 2 straipsnio 3 dalyje nustatytu reguliavimu konstatuotina, kad juridinis asmuo už fizinio asmens padarytą nusikalstamą veiką atsako tik esant juridinio asmens kaltei. Juridinio asmens baudžiamoji atsakomybė yra išvestinė iš fizinio asmens atsakomybės. Darytina išvada, jog BK nustatytas teisinis reguliavimas nereiškia, kad juridinio asmens kaltumas neturi būti įrodytas ịstatymo nustatyta tvarka ir pripažintas įsiteisèjusiu teismo nuosprendžiu; įrodyta fizinio asmens, padariusio nusikalstamą veiką, kalte yra tik prielaida nustatyti juridinio asmens kaltę ${ }^{16}$.

„Sprendžiant, ar juridinis asmuo kaltas BK 20 straipsnio 2 dalies prasme, reikia atsižvelgti j kaltininko - fizinio asmens bei jo padarytos nusikalstamos veikos ryši su juridiniu asmeniu. $<\ldots>$ Nagrinèjant konkrečia byla juridinio asmens strategija turètu büti vertinama atsižvelgiant i juridinio asmens veiklos kryptis, tikslus, numatomas perspektyvas ir pan. Teisiškai reikšminga ryši tarp fizinio asmens padarytos nusikalstamos veikos ir juridinio asmens padeda atskleisti juridinio asmens veikla reglamentuojantys norminiai aktai, organizacinè struktūra, veiklos formavimas, igyvendinimas ir pan. Svarbu tai, ar juridinio asmens savininkas (akcininkai) užtikrino veiksminga fizinio asmens veiklos kontrole, ar toleravo atitinkama veikla ir kita. Nustatant ryši tarp fizinio asmens padarytos nusikalstamos veikos ir juridinio asmens, reikia jvertinti, ar fizinio asmens padaryta nusikalstama veika ir jos sukeliamais padariniais buvo suinteresuotas juridinio asmens savininkas (akcininkai). Tai, kad juridinio asmens savininkas (akcininkai) nežinojo, neskatino arba nesudarè sąlygu fizinio asmens neteisètiems veiksmams,

14 Lietuvos Aukščiausiojo Teismo Baudžiamujų bylų skyriaus 2011 m. birželio 28 d. nutartis baudžiamojoje byloje Nr. 2K-345/2011.

15 Lietuvos Aukščiausiojo Teismo Baudžiamujų bylų skyriaus $2011 \mathrm{~m}$. birželio 28 d. nutartis baudžiamojoje byloje Nr. 2K-345/2011; Lietuvos Aukščiausiojo Teismo Baudžiamujų bylų skyriaus 2011 m. balandžio 12 d. nutartis baudžiamojoje byloje Nr. 2K-175/2011.

16 Lietuvos Aukščiausiojo Teismo Baudžiamujų bylų skyriaus $2012 \mathrm{~m}$. sausio $10 \mathrm{~d}$. nutartis baudžiamojoje byloje Nr. 2K-P-95/2012. 
yra viena iš aplinkybiu, pagal kurias sprendžiama apie juridinio asmens baudžiamaja atsakomybę. Taigi juridinio asmens savininkas ar pagrindiniai juridinio asmens akcininkai, kurie turi sprendžiamojo balso teise, fizinio asmens (kurio igaliojimai nustatyti BK 20 straipsnio 2 dalyje) nusikalstamus veiksmus turi suvokti ir skatinti arba suvokti ir juos toleruoti. Sprendžiant juridinio asmens kaltumo ir baudžiamosios atsakomybės klausima, toks abipusis ryšys tarp kaltininko - fizinio asmens ir trauktino baudžiamojon atsakomybèn juridinio asmens turi būti nustatytas. "17

Antai baudžiamojoje byloje kasatorius teigè, kad teismai nepagrịstai sutapatino V. R. kaltę su UAB ,T.“ kalte, kuri turèjo būti nustatinėjama atskirai. Lietuvos Aukščiausiasis Teismas byloje konstatavo, kad byloje juridinio asmens kaltumas buvo ịrodytas įstatymo nustatyta tvarka. Teismai savo išvadas dèl UAB „T.“ kaltès grindè ne prielaidomis, o išsamia bylos duomenų analize, t. y. vadovavosi nuosekliais nuteistụjų parodymais, kuriuos patvirtino kiti bylos duomenys - specialisto išvada ir iš dalies kitų liudytojų parodymai ${ }^{18}$.

\section{Procesiniai bylų dèl juridinių asmenų padarytų nusikalstamų veikų aspektai}

\subsection{Trauktino baudžiamojon atsakomybèm juridinio asmens atstovas}

Baudžiamojo proceso kodekso 388 straipsnio 1 dalyje numatyta, jog juridinio asmens atstovu gali būti juridinio asmens vadovas ar darbuotojas arba advokatas, juridinio asmens ịgaliotas būti atstovu procese. Juridinio asmens atstovu negali būti juridinio asmens vadovas, jeigu jis pats kaip fizinis asmuo traukiamas baudžiamojon atsakomybèn už padaryta nusikalstama veika (išskirta aut.).

Baudžiamojoje byloje Vilniaus apygardos teismas nurodè, kad apeliacinis skundas dèl Vilniaus miesto 2-ojo apylinkès teismo priimto nuosprendžio, kuriuo juridinis asmuo UAB „,K“ nuteistas pagal BK 202 straipsnio 1 dalị, 222 straipsnio 1 dalị, paduotas bendrovės vadovo A. S. Vilniaus apygardos teismas pažymėjo, kad iš bylos dokumentų matyti, jog UAB „,K“ direktorius šioje byloje pats turi nuteistojo statusą. Tais atvejais, kai juridinio asmens vadovas pats yra patrauktas baudžiamojon atsakomybèn, jis pripažintinas netinkamu trauktino baudžiamojon atsakomybėn juridinio asmens atstovu ir atstovauti juridiniam asmeniui neturi teisès. Teismas konstatavo, kad atsižvelgiant ị tai, jog A. S., būdamas UAB ,K“ vadovu, šioje byloje pats turi nuteistojo statusą, negali būti pripažintas tinkamu juridinio asmens $\mathrm{UAB}, \mathrm{K}^{\prime \prime}$ atstovu ${ }^{19}$. Analogiškas nuostatas pateikia Lietuvos apeliacinis teismas kitoje baudžiamojoje byloje. Juridinio asmens UAB „R“" atstovu buvo paskirtas šio juridinio asmens vadovas T. S. Teismas konstatavo, kad juridinio asmens vadovas, pagal BPK 388 straipsnio 1 dalies nuostatas, šioje byloje

17 Ibid.

18 Lietuvos Aukščiausiojo Teismo Baudžiamujjų bylų skyriaus $2011 \mathrm{~m}$. birželio 28 d. nutartis baudžiamojoje byloje Nr. 2K-345/2011.

19 Vilniaus apygardos teismo 2012 m. balandžio 19 d. nutartis baudžiamojoje byloje Nr. 1A-264-303-2012. 
negalejo atstovauti juridiniam asmeniui, traukiamam baudžiamojon atsakomybèn, nes jis pats buvo patrauktas baudžiamojon atsakomyben kaip fizinis asmuo už analogiškas nusikalstamas veikas, padarytas jo vadovaujamo juridinio asmens naudai ${ }^{20}$.

\subsection{Juridiniams asmenims taikomos procesinès prievartos priemonès}

Juridiniam asmeniui gali būti taikomos laikinos procesinès prievartos priemonès: laikinas juridinio asmens veiklos sustabdymas; laikinas juridinio asmens veiklos apribojimas. Šios laikinos procesinės prievartos priemonès skiriamos, jeigu trauktino baudžiamojon atsakomybėn juridinio asmens veikla gali sukliudyti netrukdomą baudžiamosios bylos procesą, taip pat gali pažeisti ūkininkavimo tvarką, padaryti žalos finansams, gamtai, visuomenės saugumui ir intelektinei nuosavybei (BPK 389 straipsnis). Nurodyti pagrindai yra alternatyvūs (išskirta aut.), todèl pakanka bent vieno iš jų, kad procesinè prievartos priemonè būtu pritaikyta. Taigi šiomis procesinėmis prievartos priemonėmis siekiama užtikrinti netrukdomą baudžiamajji procesą, užkirsti kelią juridiniam asmeniui pažeisti ūkininkavimo tvarką, padaryti žalos finansams, gamtai, visuomenès saugumui bei intelektinei nuosavybei. Siekiant šių tikslų, juridinio asmens veikla, apibrëžta tam tikruose steigimosi ar kituose vidaus tvarka reglamentuojančiuose teisès aktuose (išskirta aut.), gali būti laikinai apribota arba sustabdyta. Taip pat pažymètina, kad BPK 11 straipsnyje įtvirtintas proporcingumo principas suponuoja pareigą teismui, priimant kiekvieną sprendimą, susijusị su asmens, taip pat ir juridinio asmens, teisių ir laisvių suvaržymu, kruopščiai tikrinti ir įvertinti, ar toks suvaržymas nebus per griežtas ir neteisètas ${ }^{21}$.

Juridinio asmens veikla laikinai sustabdyta yra tada, kai juridinis asmuo ịpareigojamas laikinai nutraukti visą steigimo dokumentuose numatytą ūkinę, komercinę, finansinę ar profesinę veiklą ir uždaryti visus padalinius.

Antai kooperatinei bendrovei, kuri buvo itariama padariusi nusikalstamas veikas, numatytas BK 20 straipsnio 2 dalyje, 228 straipsnio 2 dalyje ir 20 straipsnio 2 dalyje, 182 straipsnio 2 dalyje, apylinkès teismo nutartimi buvo paskirta laikina procesinè prievartos priemonè - laikinas juridinio asmens veiklos sustabdymas 6 mėnesiams, ịpareigojant bendrovę nutraukti visą steigimo dokumentuose numatytą ūkinę, komercinę, finansinę veiklą. Juridinio asmens - kooperatinès bendrovès - veiklos sustabdymas buvo pratęstas dar trims ménesiams. Kooperatinès bendrovès atstovas skundu prašè panaikinti skundžiamą nutartị. Teige, kad teismas visiškai neanalizavo bylos duomenų; nurodè, jog skundžiama nutartis yra formali, nemotyvuota. Apygardos teismas išnagrinėjęs skundą konstatavo, kad teismas pratęsė procesinę prievartos priemonę esant ịstatyme numatytiems pagrindams - siekdamas užkirsti kelią ūkininkavimo tvarkos pažeidimams, finansinès žalos atsiradimui, t. y. laikydamasis BPK 389 straipsnyje numatytų nuostatų. Teismo išvados buvo pagrịstos ikiteisminio tyrimo medžiagos duomenimis. Esant pagrịstam ịtarimui, jog kooperatinės bendrovės paraiškoje paramai gauti yra įrašyti neteisingi duomenys, atsižvelgiant ị tai, jog Nacionalinè mokejjimo agentūra prie

20 Lietuvos apeliacinio teismo 2010 m. gegužès 17 d. nuosprendis baudžiamojoje byloje Nr. 1A-193/2010.

21 Lietuvos apeliacinio teismo $2013 \mathrm{~m}$. kovo 19 d. nutartis baudžiamojoje byloje Nr. 1N-47/2013. 
Žemės ūkio ministerijos neatsisakè šiai bendrovei suteikti paramą, o tik pratęsė paramos sutarties rengimui reikalingų papildomų dokumentų pateikimo terminą iki tos datos, iki kurios yra sustabdyta bendrovès veikla, apylinkès teismo išvada, kad tolesnè kooperatinès bendrovès veikla gali pažeisti ūkininkavimo tvarką bei padaryti žalos finansams, buvo pripažinta pagrịsta. Nurodoma, kad įtariamam juridiniam asmeniui taikoma procesinè prievartos priemonè nepažeidžia BPK 11 straipsnyje ịtvirtinto proporcingumo principo, taip pat maksimalūs šios priemonės taikymo terminai pažeisti nebuvo ${ }^{22}$.

Juridinio asmens veikla laikinai apribota yra tada, kai juridiniam asmeniui uždraudžiama užsiimti tam tikra steigimo dokumentuose numatyta veikla ir juridinis asmuo ipareigojamas uždaryti tam tikrą juridinio asmens padalinị. Teismų praktikoje paprastai ši procesinè prievartos priemonè skiriama siekiant uždrausti juridiniam asmeniui, kuriam pareikšti įtarimai ar kaltinimai padarius nusikalstamą veiką, verstis ta steigimo dokumentuose numatyta veikla, kurią vykdant galimai ir buvo padarytos inkriminuojamos nusikalstamos veikos. Pavyzdžiui, Klaipėdos miesto apylinkès teismas $2008 \mathrm{~m}$. gruodžio $5 \mathrm{~d}$. nutartimi laikinai trijų mėnesių laikotarpiui - nuo $2008 \mathrm{~m}$. gruodžio $5 \mathrm{~d}$. iki 2009 m. kovo 5 d. - apribojo UAB ūkinę veiklą, uždraudžiant kraujo komponentų saugojimą ir paskirstymą UAB Klaipėdos mobiliajame punkte. Ikiteisminio tyrimo teisejjas nutartyje nurodė, kad iš Valstybinès akreditavimo sveikatos priežiūros veiklai tarnybos prie Sveikatos apsaugos ministerijos rašto matyti, kad UAB turi išduotą įstaigos asmens sveikatos priežiūros licenciją. Tačiau ši licencija suteikè teisę UAB teikti kraujo donorystės paslaugas Kaune bei laboratorinès diagnostikos paslaugas, o UAB licencija vykdyti kraujo donorystès veiklą Klaipėdoje išduota nebuvo. „Kaip matyti iš byloje esančiu duomenu, UAB (duomenys neskelbtini) licencija, suteikianti teise vykdyti kraujo donorystès veikla (duomenys neskelbtini), Klaipèdos m., išduota néra, todèl ši veikla gali būti, kad yra vykdoma neteisètai." Daroma išvada, kad UAB veikoje yra nusikalstamos veikos, numatytos BK 202 straipsnio 1 dalyje, požymių. Teismas nutartyje pažymėjo, kad gali būti, kad trauktino baudžiamojon atsakomybėn juridinio asmens UAB veikla pažeidžia ūkininkavimo tvarką, „nes nuo 2008-04-01 UAB (duomenys neskelbtini) Klaipédos mobilusis punktas, adresu (duomenys neskelbtini), Klaipédoje, neturédamas licencijos kraujo donorystei, vykdydamas dali šios veiklos - kraujo komponentu saugojima ir paskirstyma, pažeidžia Lietuvos Respublikos sveikatos priežiūros ịstaigu istatymo (Žin., 1998, Nr. 109-2995) 45 str. 3 p. nuostata-teikti tiktas asmens sveikatos priežiūros paslaugas, kurios nurodytos istaigai išduotoje licencijoje bei Lietuvos Respublikos sveikatos apsaugos ministro 2007 m. kovo 2 d. issakymu Nr. V-156 (Žin., 2007, Nr. 31-1148) patvirtintu Asmens sveikatos istaigu licencijavimo taisykliu 50.3 p. nuostata-užsiimti licencijoje nurodyta veikla tik licencijoje nurodytais adresais, tokiu büdu $U A B$ (duomenys neskelbtini) Klaipèdos mobiliojo punkto vykdoma veikla viršija Sveikatos apsaugos ministro 2006 m. birželio 20 d. isakymu Nr. V-516 patvirtintu „, Kraujo donorystès istaigu kokybès sistemos standartu ir specifikaciju“ " 3 p. nurodyta mobiliuju punktu veikla, UAB (duomenys neskelbtini) yra skirtinos procesinès prievartos priemo- 
nès - laikinas ükinès veiklos apribojimas uždraudžiant kraujo komponentu saugojima ir paskirstyma UAB (duomenys neskelbtini) Klaipédos mobiliajame punkte $<\ldots>$. ${ }^{\text {"23 }}$

\section{Išvados}

Juridinio asmens sąvokos, svarbios BK 20 straipsnio prasme, turi būti aiškinamos ne tik sistemiškai tarpusavyje, bet ir kartu su kituose ịstatymuose ịtvirtintomis nuostatomis, reguliuojančiomis juridinio asmens steigimą, likvidavimą, pertvarkymą, teisių ir pareigu igyvendinimą ir kt.

BK 20 straipsnio 2 dalyje nustatyti fizinio asmens specifiniai požymiai - vadovaujančias pareigos juridiniame asmenyje ir teise arba atstovauti juridiniam asmeniui, arba priimti sprendimus juridinio asmens vardu, arba kontroliuoti juridinio asmens veikla - yra viena iš privalomų sąlygų norint patraukti juridinį asmenį baudžiamojon atsakomybèn.

Konstatuojant juridinio asmens baudžiamosios atsakomybės sąlygą - „nusikalstamos veikos padarymas individualiai ar juridinio asmens vardu ir juridinio asmens naudai arba jo interesais" - turi būti nustatyta, kad iš nusikalstamos fizinio asmens veikos juridinis asmuo turi (turès) naudos ir tą naudą pripažista arba juridinis asmuo suinteresuotas tokia veika ir jos sukuriamais padariniais. Juridinio asmens nauda ar interesas yra alternatyvios jo atsakomybès sąlygos. „Intereso“ sąvoka platesnè nei „naudos“ sąvoka ir gali apimti pastarają.

Juridinio asmens kaltumas turi būti įrodytas įstatymo nustatyta tvarka ir pripažintas įsiteisèjusiu teismo nuosprendžiu. Iૃrodyta fizinio asmens, padariusio nusikalstamą veiką, kaltė yra tik prielaida juridinio asmens kaltès nustatymui.

Juridinio asmens atstovu baudžiamajame procese negali būti juridinio asmens vadovas, jeigu jis pats kaip fizinis asmuo traukiamas baudžiamojon atsakomybèn už padarytą nusikalstamą veiką.

BPK 389 straipsnyje nurodyti laikinų procesiniu prievartos priemonių pagrindai yra alternatyvūs. BPK 11 straipsnyje įtvirtintas proporcingumo principas suponuoja pareigą teismui, priimant kiekvieną sprendimą, susijusị su juridinio asmens teisių ir laisvių suvaržymu, kruopščiai tikrinti ir įvertinti, ar toks suvaržymas nebus per griežtas ir neteisètas.

\section{Literatūra}

Ažubalytė, R.; Jurgaitis, R.; Zajančkauskienė,

J. Specifinès baudžiamojo proceso rūšys.

Vilnius: Mykolo Romerio universitetas, 2011.
Klaipėdos apygardos teismo Baudžiamujų bylų skyriaus $2008 \mathrm{~m}$. gruodžio $23 \mathrm{~d}$. nutartis baudžiamojoje byloje Nr. 1S-270-361/2008.

23 Klaipèdos apygardos teismo Baudžiamujjų bylų skyriaus $2008 \mathrm{~m}$. gruodžio $23 \mathrm{~d}$. nutartis baudžiamojoje byloje Nr. 1S-270-361/2008. 
Lietuvos apeliacinio teismo $2013 \mathrm{~m}$. kovo $19 \mathrm{~d}$. nutartis baudžiamojoje byloje $\mathrm{Nr} .1 \mathrm{~N}-$ 47/2013.

Lietuvos apeliacinio teismo $2010 \mathrm{~m}$. gegužès 17 d. nuosprendis baudžiamojoje byloje Nr. 1A-193/2010.

Lietuvos Aukščiausiojo Teismo Baudžiamuju bylų skyriaus $2010 \mathrm{~m}$. balandžio $27 \mathrm{~d}$. nutartis baudžiamojoje byloje Nr. 2K-269/2010.

Lietuvos Aukščiausiojo Teismo Baudžiamujuc bylų skyriaus $2010 \mathrm{~m}$. liepos $2 \mathrm{~d}$. nutartis baudžiamojoje byloje Nr. 2K-355/2010.

Lietuvos Aukščiausiojo Teismo Baudžiamujų bylų skyriaus $2010 \mathrm{~m}$. lapkričio $9 \mathrm{~d}$. nutartis baudžiamojoje byloje Nr. 2K-479/2010.

Lietuvos Aukščiausiojo Teismo Baudžiamuju bylų skyriaus $2010 \mathrm{~m}$. gruodžio $14 \mathrm{~d}$. nutartis baudžiamojoje byloje Nr. 2K-575/2010.

Lietuvos Aukščiausiojo Teismo Baudžiamujų bylų skyriaus $2010 \mathrm{~m}$. gruodžio $21 \mathrm{~d}$. nutartis baudžiamojoje byloje Nr. 2K-582/2010.

Lietuvos Aukščiausiojo Teismo Baudžiamujų bylų skyriaus $2010 \mathrm{~m}$. gruodžio $23 \mathrm{~d}$. nutartis baudžiamojoje byloje Nr. 2K-581/2010.

Lietuvos Aukščiausiojo Teismo Baudžiamuju bylų skyriaus $2011 \mathrm{~m}$. balandžio $12 \mathrm{~d}$. nutartis baudžiamojoje byloje Nr. 2K-175/2011.

Lietuvos Aukščiausiojo Teismo Baudžiamujų bylų skyriaus $2011 \mathrm{~m}$. birželio $28 \mathrm{~d}$. nutartis baudžiamojoje byloje Nr. 2K-345/2011.

Lietuvos Aukščiausiojo Teismo Baudžiamųu bylų skyriaus $2011 \mathrm{~m}$. birželio $28 \mathrm{~d}$. nutartis baudžiamojoje byloje Nr. 2K-345/2011.
Lietuvos Aukščiausiojo Teismo Baudžiamujų bylų skyriaus $2012 \mathrm{~m}$. sausio $10 \mathrm{~d}$. nutartis baudžiamojoje byloje Nr. 2K-P-95/2012.

Lietuvos Respublikos baudžiamasis kodeksas. Valstybès žinios. 2000, Nr. 89-2741 (aktuali redakcija).

Lietuvos Respublikos baudžiamojo proceso kodeksas. Valstybès žinios. 2002, Nr. 37 (aktuali redakcija).

Lietuvos Respublikos civilinis kodeksas. Valstybès žinios. 2000, Nr. 74-2262 (aktuali redakcija).

Lietuvos Respublikos Konstitucinio Teismo 2009 m. birželio 8 d. nutarimas „Dèl Lietuvos Respublikos baudžiamojo kodekso 20 straipsnio 1, 2, 3 dalių (2000 m. rugsejjo 26 d. redakcija), 20 straipsnio 5 dalies (2004 m. liepos 5 d. redakcija) 43 straipsnio 4 dalies (2000 m. rugsejjo $26 \mathrm{~d}$. redakcija) atitikties Lietuvos Respublikos Konstitucijai“. Valstybès žinios. 2009, Nr. 69-2798.

Panevėžio apygardos teismo $2012 \mathrm{~m}$. rugpjūčio 30 d. nutartis baudžiamojoje byloje Nr. 1S771-366/2012.

Vilniaus apygardos teismo $2012 \mathrm{~m}$. balandžio 19 d. nutartis baudžiamojoje byloje Nr. 1A264-303-2012.

Vilniaus miesto 1 apylinkès teismo $2011 \mathrm{~m}$. vasario $4 \mathrm{~d}$. nuosprendis baudžiamojoje byloje Nr. 1-175-865/2011.

Anotacija. Darbe pateikiami kai kurie 2008-2013 m. kasacines, apeliacines bei pirmosios instancijos teismu praktikos pavyzdžiai baudžiamosiose bylose dèl juridiniu asmenu padarytu nusikalstamu veiku. Nurodomi aktualūs teisminès praktikos atvejai, aiškinantys juridinio asmens patraukimo baudžiamojon atsakomyben pagal Lietuvos Respublikos baudžiamojo kodekso 2 dali salygas. Akcentuojamas juridinio asmens kaltes nustatymas ir aptariami probleminiai procesiniai baudžiamuju bylu dèl juridiniu asmenu padarytu nusikalstamu veiku aspektai: traukiamo baudžiamojon atsakomyben juridinio asmens atstovavimas bei laikinu procesiniu prievartos priemoniu taikymas.

Reikšminiai žodžiai: juridinis asmuo, baudžiamoji atsakomybè, kalte, atstovavimas, procesinès prievartos priemonès. 


\title{
ACTUAL ISSUES ON JUDICIAL PRACTICE IN CRIMINAL PROCEEDINGS IN RESPECT OF OFFENCES COMITTED BY LEGAL PERSONS
}

\author{
Jolanta Zajančkauskienè
}

Mykolas Romeris University, Lithuania

Summary. The article focuses on some examples of appeal and cassation instance courts' judicial practice (2008-2013) in criminal proceedings in respect of offences committed by legal persons. In the beginning, actual judicial practices that can help in explaining the conditions for prosecution of a legal person under the Article 2 of the Criminal Code of the Republic of Lithuania are presented. Further, the accents on defining the legal person's foul (mea culpa) are described. In the end of the article, there are some problematic issues in the criminal proceedings in respect of offences committed by legal persons discussed, i.e. representation of a legal person who is prosecuted and application of temporary procedural coercive measures.

Keywords: legal person, criminal liability, fault, representation, procedural coercive measures.

Jolanta Zajančkauskienė, Mykolo Romerio universiteto Teisès fakulteto Baudžiamosios teisès ir proceso instituto docentè. Mokslinių tyrimų kryptys: specifinès baudžiamojo proceso rūšys, pažeidžiami asmenys baudžiamajame procese.

Jolanta Zajančkauskienė, Mykolas Romeris University, Faculty of Law, Institute of Criminal Law and Procedure, Assoc. Professor. Research interests: special forms of criminal proceedings, vulnerable persons in criminal procedure. 